\title{
Inhibin $\alpha$-subunit and the inhibin coreceptor betaglycan are downregulated in endometrial carcinoma
}

\author{
Pasquale Florio ${ }^{1}$, Pasquapina Ciarmela $^{1}$, Fernando M Reis ${ }^{2}$, Paolo Toti $^{3}$, Letizia Galleri ${ }^{1}$, Rosa Santopietro ${ }^{3}$, \\ E Tiso $^{1}$, Piero Tosi ${ }^{3}$ and Felice Petraglia ${ }^{1}$ \\ ${ }^{1}$ Clinic of Obstetrics and Gynaecology, Department of Paediatrics, Obstetrics and Reproductive Medicine, University of Siena, 53100 Siena, Italy \\ ${ }^{2}$ Department of Obstetrics and Gynaecology, University of Minas Gerais, 30130-100 Belo Horizonte, Brazil and ${ }^{3}$ Department of Human Pathology \\ and Oncology, University of Siena, 53100 Siena, Italy \\ (Correspondence should be addressed to F Petraglia; Email: petraglia@unisi.it)
}

\begin{abstract}
Objective: In the present study we evaluated the protein distribution and mRNA levels of inhibin $\alpha$-subunit and its coreceptor betaglycan in endometrial adenocarcinoma.

Design: Two groups of postmenopausal women were studied: the first group had recently diagnosed endometrial adenocarcinoma $(n=16$; age range $61-79$ years), and the second group $(n=12$; age range 64-78 years) had undergone hysterectomy for uterine prolapse and served as control. Methods: Inhibin $\alpha$-subunit and betaglycan gene expression and tissue distribution were evaluated by semiquantitative RT-PCR and immunohistochemistry respectively.

Results: Inhibin $\alpha$-subunit and betaglycan mRNAs were expressed by both healthy and tumoral endometria, but their expression was significantly lower in endometrial carcinoma $(P<0.001$, based on Student's $t$ test). Inhibin $\alpha$-subunit expression was much weaker in the glands of tumours than in non-neoplastic specimens. Betaglycan protein was identified in the epithelial cells lining non-tumoral endometrium, and in endothelial cells of both normal and tumoral endometria. Well-differentiated neoplastic cells had a faint and scarce betaglycan staining, and poorly differentiated cells did not express betaglycan at all.

Conclusions: The lower inhibin $\alpha$ and betaglycan expression in endometrial adenocarcinoma suggests that the inhibin action may be disrupted. However, the expression of betaglycan in the endothelia of the tumour vasculature suggests that a selective vascular response to inhibin may be possible in these tumours.
\end{abstract}

European Journal of Endocrinology 152 277-284

\section{Introduction}

Inhibins and activins are members of the transforming growth factor $\beta$ (TGF $\beta$ ) superfamily, a group of structurally similar but functionally diverse growth factors. While inhibins comprise an $\alpha$-subunit and a $\beta$-subunit linked by disulphide bridges, activins are homodimers comprising two inhibin $\beta$-subunits. As in other members of the TGF $\beta$ superfamily, the biological effects of activins are initiated by assembling a complex with a type II serine threonine kinase receptor (ActRII), which then activates a type I receptor and subsequently triggers intracellular signaling via Smad proteins $(1,2)$.

Although most inhibin effects are associated with its antagonism to activin, some cells bind inhibin with much higher affinity than activin due to the existence of specific inhibin-binding molecules (3). One of these molecules was recently discovered to be betaglycan, a membrane-anchored proteoglycan that operates as an inhibin coreceptor. Betaglycan binds inhibin $\alpha$-subunit with high affinity and enhances inhibin binding to ActRII through its $\beta$-subunit, thus preventing activin access to ActRII (4).

Activins and inhibins play essential roles in many biological processes including cell proliferation, differentiation, and cellular fate determination (5). Activin A is expressed and secreted by healthy human endometrium (6) and, to a greater extent, by endometrial adenocarcinoma $(7,8)$, but whether an aberrant activin signalling promotes endometrial carcinogenesis or is just part of the cancer phenotype is not known. To further complicate matters, inhibin and betaglycan could modulate the biological effect of activin on endometrial cells; therefore, evaluating these molecules is an essential step toward the understanding of activin signalling in endometrial cancer.

Thus, the present study aimed to evaluate the protein distribution and mRNA levels of inhibin- $\alpha$ subunit and betaglycan in endometrial adenocarcinoma. The study was conducted in postmenopausal women free from 
hormone therapy because the target molecules might be sensitive to steroid hormone fluctuations (9), and also because the peak incidence of endometrial cancer occurs in postmenopausal years (10).

\section{Materials and methods}

\section{Tissue collection}

Written informed consent was obtained from all patients prior to inclusion in the study, for which local human investigation committee approval was obtained.

Two groups of women were studied. Group 1 comprised postmenopausal women with endometrial adenocarcinoma ( $n=16$; age range 61-79 years), enrolled at the time of diagnosis. Pathological diagnosis was done on hysterectomy specimens, and, according to the criteria of the International Federation of Gynaecology and Obstetrics, they were classified as well $(n=9)$ or poorly differentiated $(n=7)$. Group 2 comprised postmenopausal women $(n=12$; age range, 64-78 years) who underwent hysterectomy for uterine prolapse; they served as age-matched controls. Exclusion criteria were uterine infection, all types of neoplastic diseases and current use of hormone medication.

All specimens collected were fixed by immersion in $10 \%$ buffered formalin for the immunohistochemistry study. Also, the endometrial specimens of controls $(n=12)$ and a subset of nine specimens of endometrial adenocarcinoma ( $n=6$ : well and, $n=3$ : poorly differentiated) were immediately submerged in a RNA stabilization reagent (RNAlater, Qiagen, Milan, Italy) for the extraction of total RNA, in order to perform qualitative and semiquantitative reverse transcriptase-polymerase chain reaction (RT-PCR).

\section{RT-PCR}

Samples were disrupted and homogenized with Mixer Mill MM 300 (Qiagen), and total RNA was extracted with the RNeasy Protect Mini Kit and treated with RNase-free DNase according to the instructions of the manufacturer. RNA was quantified by UV absorption, and $1 \mu \mathrm{g}$ was reverse transcribed to prepare complementary DNA (cDNA). Reaction conditions for reverse transcription were as follows: $50 \mathrm{mM}$ Tris acetate (pH 8.4), $75 \mathrm{mM}$ potassium acetate, $8 \mathrm{mM}$ magnesium acetate, $1 \mathrm{mM}$ dNTP mix, $15 \mathrm{U}$ avian RNase H-minus reverse transcriptase (Invitrogen, Milan, Italy), $40 \mathrm{U}$ RNase Out and $2.5 \mu \mathrm{M}$ oligo $\mathrm{d}(\mathrm{T})$ primers in a final volume of $20 \mu \mathrm{l}$. The reaction was run at $65^{\circ} \mathrm{C}$ for $5 \mathrm{~min}$ and $50^{\circ} \mathrm{C}$ for $40 \mathrm{~min}$, and then the enzyme was heat inactivated at $85^{\circ} \mathrm{C}$ for $5 \mathrm{~min}$. A volume of $2 \mu \mathrm{l}$ reaction product was used for PCR reaction.

PCR conditions for qualitative and semiquantitative PCR were as follows: $20 \mathrm{mM}$ Tris $-\mathrm{Cl}(\mathrm{pH} 8.4), 50 \mathrm{mM}$ $\mathrm{KCl}, 1.5 \mathrm{mM} \mathrm{MgCl}_{2}, 0.25 \mathrm{mM}$ dNTPs, $1 \mathrm{U}$ Taq DNA polymerase, recombinant (Invitrogen) and $0.4 \mu \mathrm{M}$ (final concentration) primers in $50 \mu \mathrm{l}$ total volume.

To evaluate the cDNA quality, we performed the amplification of a 97 base pair (bp) sequence of hypoxanthine phosphoribosyltransferase (HPRT) gene used as internal standard (11). HPRT primers used for amplification were as follows: 5'-GCTTGCTGG TGAAAAGGACC-3' (sense) and 5'-GTCAAGGGCATATCCTACAAC- $3^{\prime}$ (antisense). HPRT amplification was carried out for $30 \mathrm{~s}$ at $94^{\circ} \mathrm{C}, 30 \mathrm{~s}$ at $52^{\circ} \mathrm{C}$ and $12 \mathrm{~s}$ at $72^{\circ} \mathrm{C}$ for 35 cycles, followed by a final step of $10 \mathrm{~min}$ at $72^{\circ} \mathrm{C}$. All samples included in the study demonstrated detectable levels of HPRT transcript.

Inhibin specific primers used for amplification by PCR were as follows: 5'-CAGCCACAGATGCCAGCTGT-3' (sense) and 5'-CTCCGGAGGCCTCTGCAGCAGG CGCAG-3' (antisense) (12). Betaglycan-specific primers used for amplification by PCR were as follows: $5^{\prime}$-CTGTTCACCCGACCTGAAAT-3' (sense) and 5'-CGTCAGGAGGCAC ACACTTA-3' (antisense). Computer analysis performed to compare the synthesized oligomers with the human sequences in the gene database of the National Center for Biotechnology (NCBI), using BLAST (13), revealed no significant homology with all other genes. Sequence homology among the different oligomers used in the present study was also avoided, excluding possible cross-reactions. The expected size of the amplified fragment was $503 \mathrm{bp}$ for inhibin and $502 \mathrm{bp}$ for betaglycan: these fragment sizes are specific for the RNA, because the primers were located on different exons. Blank for each reaction consisted of amplifications performed in absence of reverse transcriptase enzyme (-RT).

Inhibin amplification was carried out for $30 \mathrm{~s}$ at $94^{\circ} \mathrm{C}, 20 \mathrm{~s}$ at $56^{\circ} \mathrm{C}$ and $17 \mathrm{~s}$ at $72^{\circ} \mathrm{C}$ for 35 thermal cycle steps, followed by a final step of $10 \mathrm{~min}$ at $72^{\circ} \mathrm{C}$. Betaglycan amplification was carried out for $1 \mathrm{~min}$ at $94{ }^{\circ} \mathrm{C}, 1 \mathrm{~min}$ at $62^{\circ} \mathrm{C}$ and $1 \mathrm{~min}$ at $72^{\circ} \mathrm{C}$ for 35 thermal cycle steps, followed by a final step of $10 \mathrm{~min}$ at $72^{\circ} \mathrm{C}$. Amplification products were visualized on $2 \%$ agarose gel and stained with ethidium bromide.

PCR product identity was confirmed by using a trophoblast sample as positive control $(14,15)$ and by restriction analysis for betaglycan. The betaglycanamplified fragment was digested with Van 91 I (Roche Molecular Biochemicals, Monza, Italy), under the conditions suggested by the manufacturer. The products were separated on $2 \%$ agarose gel and stained with ethidium bromide.

\section{Semiquantitative RT-PCR}

To estimate differences in mRNA inhibin and betaglycan expression between controls and the study group, a semiquantitative RT-PCR was performed by using HPRT as housekeeping gene (11). The cycle numbers for each cDNA were established after testing a range of 28-38 for inhibin, and 22-35 for betaglycan, 
in preliminary experiments, to ensure that they would not reach the plateau phase. Amplifications were carried out for 26 cycles for HPRT, 30 cycles for inhibin and 24 cycles for betaglycan. The intensity of the DNA fragments was evaluated by densitometric analysis, and then the ratio between target and standard cDNAs was calculated. Thus, data were expressed as the ratio between inhibin and betaglycan cDNAs and the corresponding HPRT cDNA. Each experiment was repeated at least three times, and similar results were always obtained.

\section{Immunohistochemistry}

Immunohistochemistry was carried out on 5- $\mu$ m-thick sections obtained from paraffin-embedded samples, mounted on electrostatically charged slides, and dried overnight at $37^{\circ} \mathrm{C}$. Sections were dewaxed, rehydrated and washed in Tris-buffered saline (TBS) (20 mM Tris$\mathrm{HCl}$ and $150 \mathrm{mM} \mathrm{NaCl}(\mathrm{pH} \mathrm{7.6)})$. Tissue sections were heated in a microwave oven two times for $5 \mathrm{~min}$ at $750 \mathrm{~W}$ (ethylenediamine tetraacetic acid (EDTA), $\mathrm{pH} 8$ ) and were rinsed in 3\% hydrogen peroxide to block endogenous peroxidase. Slides were incubated overnight at room temperature with primary antibody.

The antibody used for betaglycan was a goat polyclonal (R\&D Systems, Abingdon, UK) diluted 1:1000. The antiserum used for inhibin was a rabbit polyclonal (1:1000) provided by Professor W Vale (Salk Institute, La Jolla, CA, USA) (16). The reaction was developed by successive incubations with biotinylated antigoat or antirabbit IgG, avidin-biotin-peroxidase complex (Vector, Burlingame, CA, USA) and $1 \mathrm{mg} / \mathrm{ml} \mathrm{3,3^{ \prime } -}$ diaminobenzidine tetrahydrochloride (Sigma) in TBS containing $0.3 \% \mathrm{H}_{2} \mathrm{O}_{2}$. Harris hematoxylin was used for nuclear counterstaining. A positive reaction was characterized by the presence of granular brown staining in the cytoplasm.

Negative controls consisted of sections where the primary antibody was replaced by non-immune serum and by using the antibody preadsorbed with the blocking peptide (R\&D Systems, Milan, Italy).

\section{Assessment of staining}

The individual intensity of immunostaining of tissue section was scored by three independent assessors on a subjective scale as absent, or rare $(-)$, weak $(+)$, moderate $(++)$ or strong $(+++)$.

\section{Statistical analysis}

After confirming a normal distribution, data were summarized as means \pm standard errors (s.e.). Betweengroup differences were evaluated by unpaired $t$-test, and the statistical significance was assumed when $P<0.05$.

\section{Results}

\section{Expression of inhibin and betaglycan mRNAs}

Total RNA extracted from endometrium was analysed by RT-PCR. The predicted bands corresponding in size to inhibin ( $503 \mathrm{bp}$ ) and betaglycan (502 bp) products were obtained, and no amplified fragment caused by DNA contamination was detected in any experiment (Figs 1 and 2).

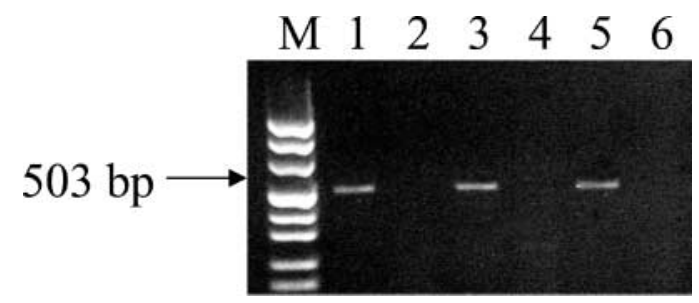

Figure 1 Representative results of RT-PCR analysis of inhibin in human endometrium. Lane M: Molecular weight marker (Marker VIII, Roche Molecular Biochemicals); lane 1: trophoblast used as positive control; lane 3: menopausal endometrium; lane 5: endometrial adenocarcinoma; lanes 2, 4, and 6 (blank): amplifications performed in absence of reverse transcriptase enzyme.

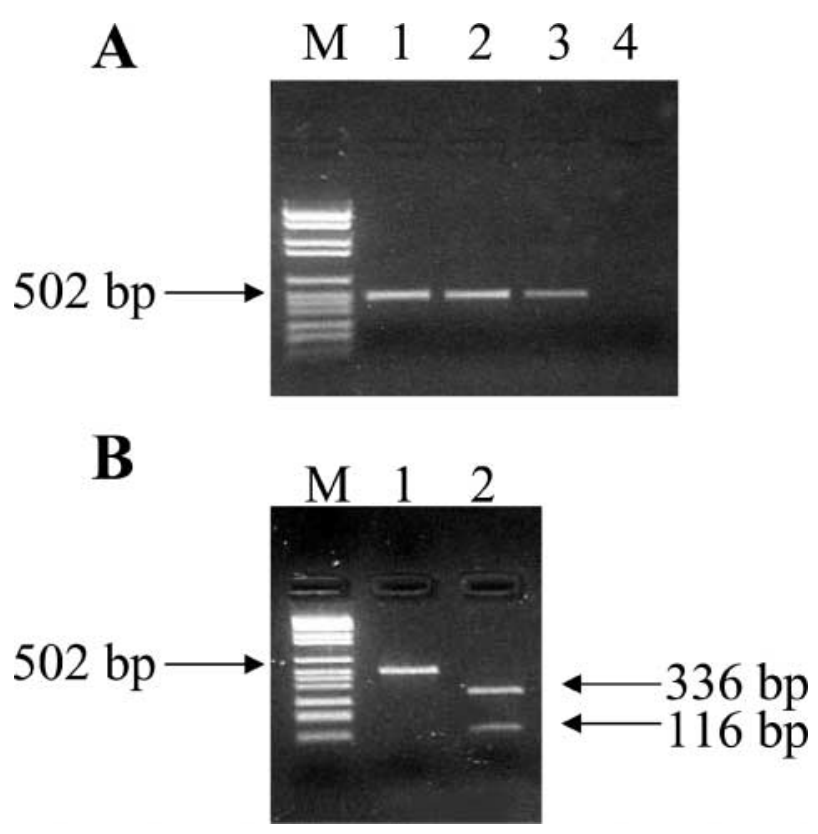

Figure 2 (A) Representative results of RT-PCR analysis of betaglycan in human endometrium. Lane M: molecular weight marker (Marker VI, Roche Molecular Biochemicals); lane 1: trophoblast used as positive control; lane 2: menopausal endometrium; lane 3: endometrial adenocarcinoma; lane 4 (blank): amplifications performed in absence of reverse transcriptase enzyme. (B) Verification of the identity of the product of betaglycan PCR (restriction analysis. Lane M: molecular weight marker (Marker VI, Roche Molecular Biochemicals); lane 1: PCR fragment; lane 2: PCRdigested fragment using Van $91 \mathrm{I}$. The sizes of the fragments are indicated. 
When evaluated by semiquantitative RT-PCR, the expression of both inhibin and betaglycan mRNA (expressed as the inhibin/HPRT and betaglycan/HPRTA mRNA ratios respectively) was significantly $(P<0.001)$ lower in endometrial carcinoma than in healthy endometrium (Fig. 3).

\section{Localization of inhibin peptide}

In postmenopausal non-neoplastic endometrium, immunoreactive inhibin was diffusely found in the cytoplasm of endometrial glands (Fig. 4A, black arrows) and luminal endometrial cells (Fig. 4A, white arrows). In the stroma, inhibin- $\alpha$-positive cells were most abundant close to the superficial layers (Fig. 4A, asterisks). Vessel walls and myometrial cells were unstained (not shown).

In contrast, only a few cells were immunostained in endometrial tumour samples. In well-differentiated (grades 1-2) neoplasias, inhibin $\alpha$ immunoreactivity
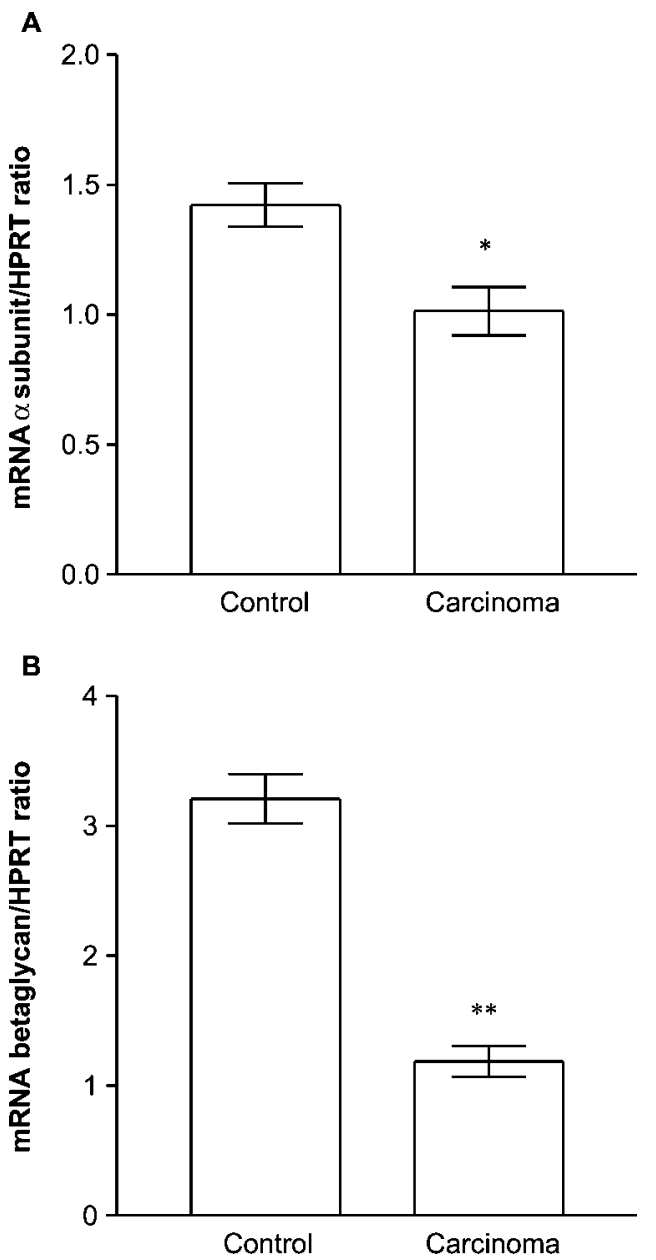

Figure 3 Relative abundance of inhibin/HPRT mRNA (A) and betaglycan/HPRT mRNA (B) in normal and tumoral human endometrium. Data are expressed as means \pm S.E. ${ }^{\star} P<0.01$; ${ }^{* *} P<0.001$ (Student's $t$-test). was scarce, and the stain was restricted to the apical or basal cytoplasm of glandular epithelial cells (Fig. 4B-D, arrows). Epithelial glands of histological variants, such as clear-cell carcinoma, were also mostly negative (not shown). In positive cells, it was possible to identify two different patterns of stain, that is, a diffuse stain in the cytoplasm of neoplastic cells (Fig. 4C and D, arrows), or a dotted stain in the apical or basal part of the neoplastic cells (Fig. 4B, arrows). The lumen of neoplastic glands was sometimes also filled with immunopositive material (Fig. 4D, arrowhead). In contrast, neoplastic cells in poorly differentiated (grade 3) tumours were negative for inhibin immunostain (Fig. 4E). Vessel walls and myometrial cells were unstained in all tissues evaluated (not shown), as well as intratumoral vessel walls and stromal cells.

Semiquantitatively, the staining pattern was more intense in healthy controls then in endometrial cancer (Table 1).

\section{Localization of betaglycan peptide}

In healthy controls, betaglycan immunoreactivity appeared consistently and diffusely located on vascular endothelial cells lining small arteries, capillaries and veins, both in the endometrium (Fig. 5A, arrowhead) and in the myometrium (data not shown). Betaglycan also stained the endometrial epithelial cells (glands), and the staining was particularly abundant in the basal and apical borders of the cell, while the central part presented reduced or no staining (Fig. 5A, arrows).

Betaglycan localization was also evaluated in welland poorly differentiated endometrial carcinoma. Well-differentiated adenocarcinoma featured a weak and patchy immunostaining for betaglycan. As shown in Fig. 5B (arrow), there were rare stained epithelial glands in the well-differentiated adenocarcinomas, while the poorly differentiated (grade 3) ones were devoid of stain in endometrial components (Fig. 5E). Endothelial cells of tumour vessels were constantly depicted by strongly positive betaglycan immunostain (Fig. 5C and D, arrowheads), serving also as positive internal control.

On a semiquantitative scale, the betaglycan-staining pattern was more intense in healthy controls than in endometrial cancer (Table 1).

\section{Discussion}

Our concordant immunohistochemical and RT-PCR results firstly demonstrate the expression of inhibin $\alpha$-subunit in the endometrium of postmenopausal women. We also observed that inhibin $\alpha$-subunit is localized predominantly in the glandular epithelium, albeit some stromal cells can also express the protein. In the present study, we also first demonstrate that human postmenopausal endometrium expresses both 

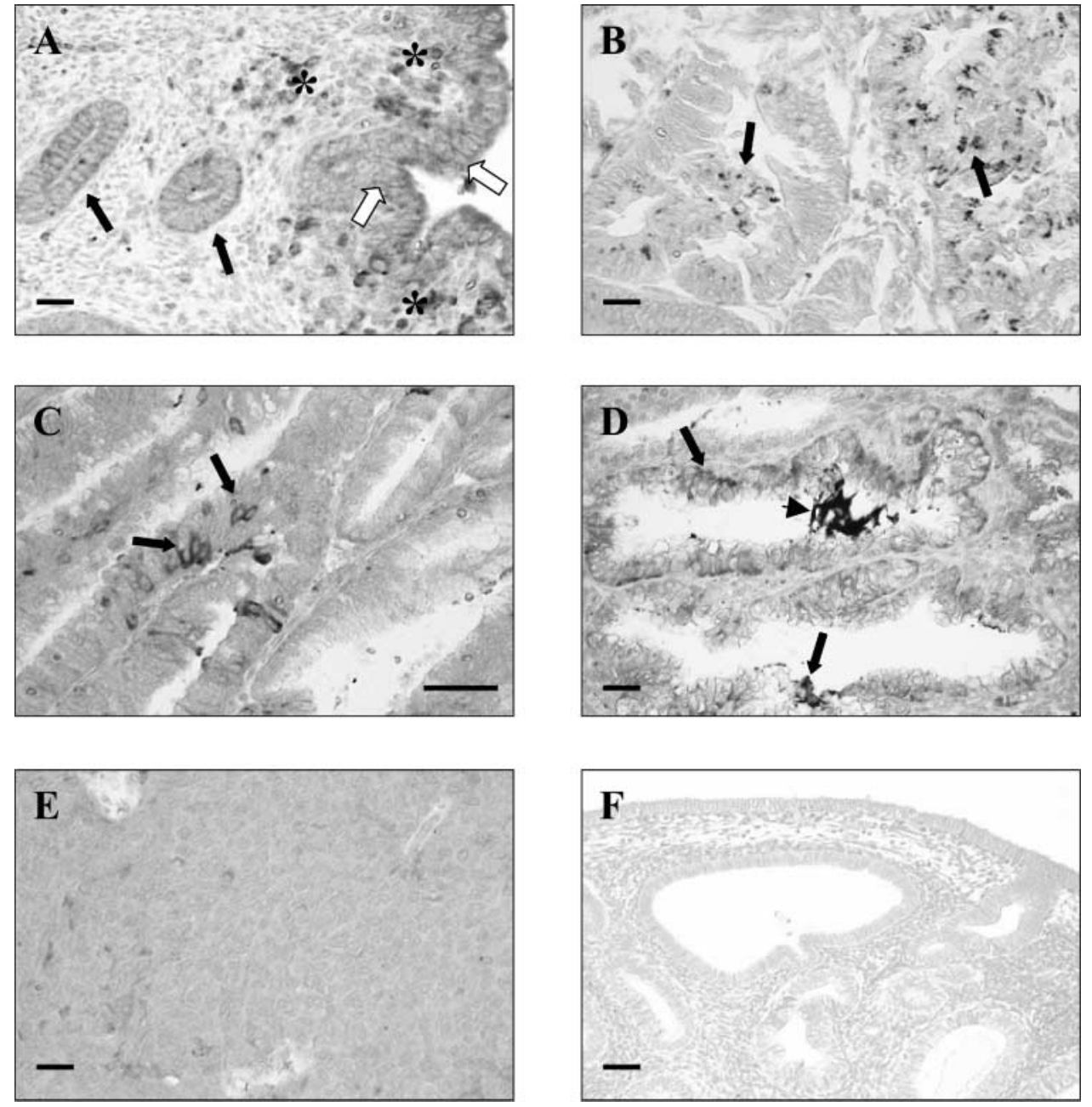

Figure 4 (A) Postmenopausal non-neoplastic endometrium. Cytoplasm of the endometrial gland (black arrows) and luminal endometrial cells (far right, white arrows) show diffuse inhibin $\alpha$ immunoreactivity. In the stroma, positive inhibin cells are more abundant near the superficial layers (asterisks). (B-D) Well-differentiated endometrioid adenocarcinoma. Inhibin $\alpha$ immunoreactivity in neoplastic cells has a focal and patchy appearance. In panel $B$, dots of positivity in the apical or basal part of the neoplastic cells are shown; in panels $C$ and $D$, an intense stain is visible in the cytoplasm of a few neoplastic cells (arrows). In panel $\mathrm{D}$, a positive immunoreaction is also present in the lumen of neoplastic glands (arrowhead). Intratumoral vessel walls and stroma cells were unstained in all tissues evaluated. (E) Poorly differentiated (grade 3) endometrial adenocarcinoma. Neoplastic cells are negative for inhibin $\alpha$ immunostain. (F) Negative control. Scale bar $=50 \mu \mathrm{m}$. betaglycan mRNA and protein, and that betaglycan is localized mainly in glandular epithelium and vascular endothelial cells of small arteries, capillaries and veins in the endometrium as well as in the myometrium.

The endometrium of fertile women has already been described as a site of inhibin and betaglycan expression; with the same antibody, betaglycan was localized in stromal, epithelial and endothelial cells of cycling endometrium $(6,9)$. However, by comparing those findings with our present results, we can conclude that betaglycan is not expressed by postmenopausal stromal cells, thus suggesting that these endometrial components

Table 1 Relative abundance of inhibin and betaglycan stain in normal and tumoral human endometrium.

\begin{tabular}{lccllll}
\hline & \multicolumn{2}{c}{ Inhibin } & & \multicolumn{2}{c}{ Betaglycan } \\
\cline { 2 - 3 } \cline { 6 - 7 } \cline { 5 - 6 } & Control & Carcinoman & & Control & Carcinoma \\
\hline Epithelium & ++ & + & & +++ & - \\
Stroma & ++ & - & & - & - \\
Vascular endothelium & - & - & & +++ & +++ \\
\hline
\end{tabular}

-Absent or rare; + weak; ++ moderate; +++ strong. are not specific inhibin targets in the postmenopausal uterus.

In contrast to normal postmenopausal endometrium, tumour specimens had a markedly low inhibin expression in the glands and no expression at all in the stroma. Experimental data have ascribed to inhibin a tumour-suppressing role, since knockout mice lacking the inhibin $\alpha$-subunit gene develop gonadal stromal tumours (17). Clinical observations have suggested that epithelial ovarian tumours have an unbalanced expression of inhibin and activin subunits that may contribute to abnormal cell proliferation (18). Moreover, the expression of the inhibin $\alpha$-subunit gene is suppressed in the malignant regions of prostate tissue (19).

As for the uterine expression, inhibin $\alpha$-subunit mRNA is found in endometrial and cervical malignant tumours (7), but its possible role remains unclear. A recent immunohistochemistry study of cycling women showed that inhibin $\alpha$-subunit expression tends to decrease from lower to higher grade adenomatous hyperplasia and adenocarcinoma (20). Nevertheless, it is still premature to suggest that low inhibin 

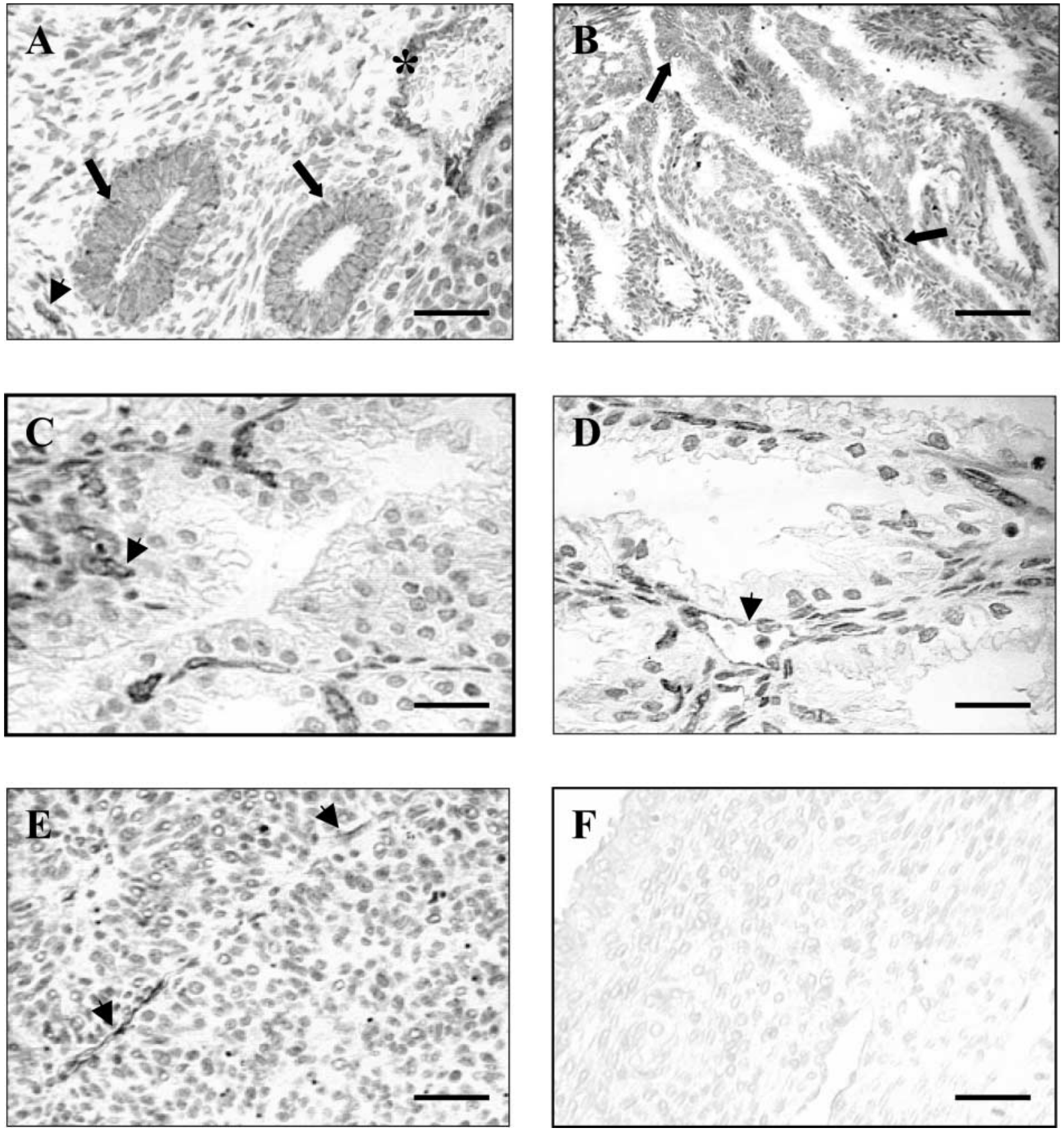

Figure 5 Betaglycan immunolocalization in human endometrium. (A) Normal non-neoplastic endometrium; epithelial cells of endometrial glands are consistently stained (arrows). Intense positivity was found in endothelial cells (the asterisk indicates a vein; the arrowhead shows a capillary). (B-D) Well-differentiated endometrioid adenocarcinoma shows weak and patchy immunostaining for betaglycan (indicated by the arrows). (E) Poorly differentiated adenocarcinoma are unstained. Endothelial cells of intratumoral vessels (B-E) are positive for betaglycan immunostain (indicated by arrowheads); they also served as positive internal controls. (F) Negative control. Scale bar $=50 \mu \mathrm{m}$.

$\alpha$-subunit expression plays a role in the neoplastic transformation of premalignant endometrial diseases. An alternative hypothesis is that neoplastic cells show a decreased inhibin gene expression as part of their phenotype, not necessarily with etiopathogenic implications.

Another finding of the present study is that betaglycan expression was significantly lower in endometrial cancer than in non-neoplastic postmenopausal endometria, indicating that in malignant endometrium also the potential to respond to inhibin is compromised. However, the functional consequences of this reduced availability of inhibin-binding sites in the endometrium is still unknown. Put in the context of activin signalling modulation, the lower inhibin $\alpha$-subunit and betaglycan expression should contribute in the same direction 
to increase activin biological effects. As we have recently demonstrated that other critical activinmodulating molecules - follistatin and follistatinrelated gene - are either decreased or unchanged in endometrial adenocarcinoma (21), the net result strongly suggests activin signalling.

Betaglycan increases cell responsiveness to TGF $\beta$ by presenting the ligand to its signalling type II receptor (22). Actually, it was formerly known as TGF $\beta$ type III receptor. Thus, besides the inhibin/activin pathway, the lower betaglycan expression in endometrial carcinoma may also lead to a decreased endometrial responsiveness to TGF $\beta$, which is a natural modulator of endometrial cell proliferation (23).

The present study also showed that betaglycan is expressed in endothelial cells of both normal and tumoral endometrium. Whether betaglycan plays a role in regulating endothelial cell function and/or neoangiogenesis in the endometrium is difficult to determine from the currently available evidence. Activin has been shown to inhibit the in vitro proliferation of four types of non-tumoral endothelial cells, but inhibin failed to antagonize activin effects on these cell types (24), an unexpected finding for a cell expressing betaglycan (2). Conversely, it is possible that the presence of betaglycan facilitates the antiproliferative effect of TGF $\beta$ that has been demonstrated in cultured endothelial cells (25).

In conclusion, we demonstrated a low inhibin $\alpha$ and betaglycan mRNA and protein expression in endometrial adenocarcinoma, suggesting that the inhibin/activin pathway and the TGF $\beta$ signalling may be disrupted. However, the expression of betaglycan in the endothelia of the tumour vasculature suggests that a selective vascular response to TGF $\beta$ and inhibin may be possible in these tumours.

\section{References}

1 Bernard DJ, Chapman SC \& Woodruff TK. Mechanisms of inhibin signal transduction. Recent Progress in Hormone Research 200156 417-450.

2 Gray PC, Bilezikjian LM \& Vale W. Antagonism of activin by inhibin and inhibin receptors: a functional role for betaglycan. Molecular and Cellular Endocrinology $2002 \mathbf{1 8 8}$ 254-260.

3 Lebrun JJ \& Vale WW. Activin and inhibin have antagonistic effects on ligand-dependent heteromerization of the type I and type II activin receptors and human erythroid differentiation. Molecular and Cellular Biology 199717 1682-1691.

4 Lewis KA, Gray PC, Blount AL, MacConell LA, Wiater E, Bilezikjian LM \& Vale W. Betaglycan binds inhibin and can mediate functional antagonism of activin signalling. Nature $2000 \mathbf{4 0 4}$ 411-414.

5 Florio P, Rossi M, Sigurdardottir M, Ciarmela P, Luisi S, Vigano P, Grasso D, Fiore G, Cobellis L, Di Blasio AM \& Petraglia F. Paracrine regulation of endometrial function: interaction between progesterone and corticotropin-releasing factor (CRF) and activin A. Steroids $2003 \mathbf{6 8} 801-807$.
6 Leung PH, Salamonsen LA \& Findlay JK. Immunolocalization of inhibin and activin subunits in human endometrium across the menstrual cycle. Human Reproduction 199813 3469-3477.

7 Petraglia F, Florio P, Luisi S, Gallo R, Gadducci A, Vigano P, Di Blasio AM, Genazzani AR \& Vale W. Expression and secretion of inhibin and activin in normal and neoplastic uterine tissues. High levels of serum activin A in women with endometrial and cervical carcinoma. Journal of Clinical Endocrinology and Metabolism $1998 \mathbf{8 3} 1194-1200$.

8 Otani T, Minami S, Yamoto M \& Umesaki N. Production of activin A in hyperplasia and adenocarcinoma of the human endometrium. Gynecologic Oncology 200183 31-38.

9 Jones RL, Salamonsen LA, Zhao YC, Ethier JF, Drummond AE \& Findlay JK. Expression of activin receptors, follistatin and betaglycan by human endometrial stromal cells; consistent with a role for activins during decidualization. Molecular Human Reproduction $20028363-374$.

10 National Cancer Institute: Surveillance, epidemiology, and end results. 2004 Available online at http://www.cancer.gov

11 Gorzelniak K, Janke J, Engeli S \& Sharma AM. Validation of endogenous controls for gene expression studies in human adipocytes and preadipocytes. Hormone and Metabolic Research 200133 625-627.

12 Reis FM, Di Blasio AM, Florio P, Ambrosini G, Di Loreto C \& Petraglia F. Evidence for local production of inhibin A and activin A in patients with ovarian endometriosis. Fertility and Sterility $200175367-373$.

13 Altschul SF, Madden TL, Schaffer AA, Zhang J, Zhang Z, Miller W \& Lipman DJ. Gapped BLAST and PSI-BLAST: a new generation of protein database search programs. Nucleic Acids Research 199725 3389-3402.

14 Petraglia F, Garuti GC, Calza L, Roberts V, Giardino L, Genazzani AR, Vale $W$ \& Meunier $H$. Inhibin subunits in human placenta: localization and messenger ribonucleic acid levels during pregnancy. American Journal of Obstetrics and Gynecology $1991 \mathbf{1 6 5} 750-758$.

15 Ciarmela P, Florio P, Toti P, Grasso D, Santopietro R, Tosi P \& Petraglia F. Expression of betaglycan in pregnant tissues throughout gestation. European Journal of Endocrinology 2003 $1491-5$.

16 Petraglia F, Anceschi MM, Calza L, Garuti GC, Fusaro P, Giardino L, Genazzani AR \& Vale W. Inhibin and activin in human fetal membranes: evidence for a local effect on prostaglandin release. Journal of Clinical Endocrinology and Metabolism 1993 77 542-548.

17 Matzuk MM, Finegold MJ, Su JJ, Hsueh AJW \& Bradley A. $\alpha$-Inhibin is a tumour-suppressor gene with gonadal specificity in mice. Nature $1992 \mathbf{3 6 0} 313-319$.

18 Zheng W, Luo MP, Welt C, Lambert-Messerlian G, Sung CJ, Zhang Z, Ying SY, Schneyer AL, Lauchlan SC \& Felix JC. Imbalanced expression of inhibin and activin subunits in primary epithelial ovarian cancer. Gynecologic Oncology 1998 $6923-31$.

19 Mellor SL, Richards MG, Pedersen JS, Robertson DM \& Risbridger GP. Loss of the expression and localization of inhibin alpha-subunit in high grade prostate cancer. Journal of Clinical Endocrinology and Metabolism $1998 \mathbf{8 3}$ 969-975.

20 Mylonas I, Makovitzky J, Richter DU, Jeschke U, Briese V \& Friese K. Expression of the inhibin-alpha subunit in normal, hyperplastic and malignant endometrial tissue: an immunohistochemical analysis. Gynecologic Oncology 200493 92-97.

21 Ciarmela P, Florio P, Sigurdardottir M, Toti P, Maguer-Satta V, Rimokh R, Altomare A, Tosi P \& Petraglia F. Follistatin-related gene expression, but not follistatin expression, is decreased in human endometrial adenocarcinoma. European Journal of Endocrinology $2004151251-257$.

22 Lopez-Casillas F, Wrana JL \& Massagué J. Betaglycan presents ligand to the TGF beta signaling receptor. Cell $1993 \mathbf{7 3}$ $1435-1444$. 
23 Ingman WV \& Robertson SA. Defining the actions of transforming growth factor beta in reproduction. Bioessays 200224 904-914.

24 McCarthy SA \& Bicknell R. Inhibition of vascular endothelial cell growth by activin-A. Journal of Biological Chemistry $19932 \mathbf{2 6 8}$ 23066-23071.

25 Baird A \& Durkin T. Inhibition of endothelial cell proliferation by type beta-transforming growth factor: interactions with acidic and basic fibroblast growth factors. Biochemical and Biophysical Research Communications 1986138 476-482.

Received 16 August 2004

Accepted 12 November 2004 